\title{
ONTOLOGICKÁ STRUKTURA SUPPOSITA V DÍLE TOMÁŠE AKVINSKÉHO ${ }^{1}$
}

\author{
DAVID SVOBODA
}

\section{1. Úvod}

tomto článku zaměříme pozornost na Tomášovo pojetí ontologické struktury supposita a vyložíme vztah supposita k přirozenosti, individuálním vymezením a aktu bytí. Konkrétně je naším cílem vysvětlit ontologickou strukturu supposita, a to $\mathrm{v}$ terminologii „celku a části“ (tzv. mereologie), nebot tímto způsobem nebyl daný problém dosud zpracován náležitým způsobem. ${ }^{2}$ Naše práce je tak zamýšlena jako příspěvek do probíhající diskuse o Tomášově mereologii. ${ }^{3}$

Tomáš pojednává o ontologické struktuře supposita nejčastěji v kontextu diskuse o vztahu supposita a prrirozenosti, a proto bude východiskem našeho výkladu Tomášovo řešení této obtíže. Problematice vzta-

1 Práce na článku byla podpořena z grantu GAAV IAA908280801.

2 Problematice ontologické struktury supposita byla již $\mathrm{v}$ zahraniční literatuře věnována určitá pozornost, ovšem výklad této obtíže z pohledu Tomášovy mereologie podává pouze, nakolik je nám známo, francouský badatel B. Bro. Srov. BRO, B. La notion métaphysique de tout et son application au problème théologique de l'union hypostatique: I - La notion de tout en Saint Thomas. Revue Thomiste 1967, roč. 67, s. 32-61; II - Analytiques de la notion de tout. Tamtéž, s. 561-583. Na Broovu práci navážeme a jeho závěry se pokusíme doplnit, upřesnit či eventuálně korigovat. K problému ontologické struktury supposita srov. např. dnes již standardní práci - WIPPEL, J. F. The Metaphysical Thought of Thomas Aquinas, From Finite Being to Uncreated Being. Monographs of the Society for Medieval and Renaissance Philosophy, Num. 1, Washington, D.C. 2000, především s. 238-252.

3 Sekundární literatura k této problematice, nakolik je nám známo, není př́liš bohatá. K tomuto námětu srov. OEING-HANHOFF, L. Das Ganze und seine substantialen Teile. In ID. Ens et unum convertuntur: Stellung und Gehalt des Grundsatzes in der Philosophie des Hl. Thomas von Aquin. Munster: Aschendorffsche Verlagsbuchhandlung, 1953, s. 155-163; ID. Ganzes/Teil. In RITTER, J. \& GRUENDER, K. (ed.). Historisches Woerterbuch der Philosophie. Sv. 3. Basel/Stuttgart: Schwabe und Co. AG, 1976, sl. 3-11; DESMOND, P. H. Medieval Mereology (Bochumer Studien zur Philosophie, Vol. 16). Amsterdam: B. R. Gruener, 1992; LOFY, C. A. The Meaning of „Potential Whole“ in St. Thomas Aquinas. The Modern Schoolman 1959, roč. 37, s. 39-48. 
hu supposita a přirozenosti věnoval pozornost již Aristotelés, ovšem pro křestansky orientované myslitele je tato problematika relevantní nejenom z hlediska filosofického, ale také z pohledu teologického, nebot' úzce souvisí s naukou o tzv. hypostatické unii. Jak známo, tato nauka byla na všeobecném koncilu v Chalcedonu (451 po Kr.) formulována tak, že Kristus je jedna hypostasis, jedna osoba se dvěma přirozenostmi: jedna přirozenost je (zcela) lidská a druhá je (naprosto) božská. Druhá božská osoba totiž přijala v určitém čase a na konkrétním místě skrze Pannu Marii individuální lidskou přirozenost, aniž by však byla Kristova lidská přirozenost ustavena jako osoba. Článkem křestanské víry je tedy tvrzení, že v Kristu jsou dvě individuální přirozenosti (božská a lidská), ale pouze jedna božská osoba, ve které jsou tyto dvě reálně odlišné přirozenosti sjednoceny. Tomášovy diskuse o vztahu supposita a přirozenosti jsou velmi často vedeny v kontextu diskuse o této christologické nauce.

Souhrně lze $\mathrm{k}$ námi sledované problematice říci, že $\mathbf{v}$ Tomášově díle lze nalézt dva různé zpo̊soby jejího řešení. Pokusím se dále oba krátce charakterizovat. První způsob řešení lze shrnout na základě Tomášovy úvahy v Quaestiones disputatae De potentia $(9,1)$, kde se pojednává o odlišnosti materiálního supposita a jeho esence. Individuální materiální substance zahrnuje podle Tomáše vedle společné přirozenosti také individuální látku a individuální akcidenty, které látku vymezují. V každém materiálním suppositu jsou ke společné přirozenosti přidána individuální vymezení, která působí numerickou odlišnost více individuí téže přirozenosti. Žádné materiální suppositum tedy není po věcné stránce totožné se svou přirozeností, nýbrž přirozenost se vztahuje k suppositu jako formální část ke svému celku. Protože v přirozenosti separovaných subsistujících substancí (teologicky řečeno andělů) není zahrnuta látka, která by individualizovala společnou přirozenost, je podle Tomáše v těchto entitách suppositum reálně totožné $s$ jejich přirozeností. ${ }^{4}$

Druhý způsob řešení uvádí Tomáš na jiném místě (Quaestiones de quodlibet 2,2,2), kde řeší tutéž problematiku na základě své nauky o reálném rozdílu esence a aktu bytí v každém konečném jsoucnu. Takto dochází k závěru, že suppositum a přirozenost se reálně liší v každé stvořené věci, nebot' každé stvořené jsoucno je reálně složeno z esence a aktu

4 Srov. De potentia. Pession, P. M. (ed.). Quaestiones disputatae II. Turin, 1965 (dále jen QDP) - „Comparatur ergo essentia ad substantiam particularem ut pars formalis ipsius [...] Et ideo in rebus, ex materia et forma compositis, essentia non est omnino idem quod subiectum [...] In substantiis vero simplicibus, nulla est differentia essentiae et subiecti, cum non sit in eis materia individualis naturam communem individuans, sed ipsa essentia in eis est subsistentia." 
bytí. Tomáš v tomto kontextu míní suppositem první substanci spolu s aktem bytí, a proto dochází k závěru, že se každé konečné suppositum liší od své přirozenosti. ${ }^{5}$

Tím jsme ve zkratce ukázali dva různé přístupy k řešení námi sledované problematiky, které se nacházejí v Tomášově díle, a nutno dodat, že Tomáš většinou užívá první uvedený způsob argumentace a tvrdí, že v separovaných substancích jsou suppositum a přirozenost reálně totožné, $v$ materiálních substancích pak reálně odlišné. $V$ dalším se budeme postupně věnovat oběma uvedeným způsobům argumentace blíže a pokusíme se ukázat „vnitřní jednotu“ Tomášova na první pohled nejednotného řešení této obtíže. Na tomto základě potom vyložíme Tomášovo pojetí ontologické struktury supposita v terminologii „celku a části“.

\section{Dva způsoby výkladu ontologické struktury supposita}

Ve třetí knize komentáře k Sentencim $(5,1,3)$ hájí Tomáš tezi, že v Kristu je pouze jedna osoba. Na úvod Tomáš poznamenává, že v některých entitách se osoba a přirozenost liší reálně, v jiných pouze pomyslně. Přirozeností zde Tomáš míní kviditu věci, kterou označuje definice, a osobou „individuum“ ( hoc aliquid), které subsistuje v této přirozenosti. ${ }^{6}$

Poté Tomáš s odkazem na Avicennu uvádí, že jednoduché nemateriální entity jsou totožné se svou kviditou, zatímco v materiálních kompozitech se kvidita a kompozitum liší, např. lidství není totožné s nějakým člověkem. To je zjevné z toho, že abstraktní termín „lidstvi“ označuje pouze esenciální principy člověka, nakolik je člověkem, a nikoli vymezení látky, jimiž je přirozenost individualizována. Tato individuální vymezení zahrnuje např. Sókratés, protože prostřednictvím těchto vymezení je Sókratés ustaven jako individuum odlišné od ostatních lidí. „Lidství“ tedy neoznačuje reálně subsistující celek, nýbrž lidství chápeme jako část subsistujícího celku, a proto se lidství o Sókratovi nevypovídá. Protože však subsistuje pouze složený celek, který má své části a nikoli lidství jako část celku, subsistuje Sókratés, jenž má lidství jako svou část. ${ }^{7}$

5 Srov. Quaestiones de quodlibet 2, 2, 2. Spiazzi, R. M. (ed.). Turin, 1956 (dále jen Quodl.).

6 Srov. Scriptum super libros Sententiarum, 5, 1, 3 (dále jen In Sent.). Mandonnet, P. Moos, M. F. (ed.). Paris 1929-1947 - „Sciendum est ergo, quod in quibusdam differunt natura et persona secundum rem, in quibusdam vero secundum rationem tantum. Natura enim, secundum quod hic loquimur, est quidditas rei quam signat sua definitio; persona autem est hoc aliquid quod subsistit in natura illa."

7 Tamtéž - „In simplicibus autem quae carent materia, ut dicit Avicenna, ipsum simplex est sua quidditas; quidditas vero compositi non est ipsum compositum: huma- 
Konkrétní termín „člověk“ naopak označuje i esenciální principy člověka jako takového i individuální vymezení, ovšem obojí označuje různým způsobem. Esenciální principy člověka jako takového označuje termín „člověk“ vymezeným způsobem, individuální vymezení tohoto nebo onoho člověka pak způsobem nevymezeným (indeterminate). „Člověk“ je (univerzální) celek, a proto lze tento predikát vypovídat o Sókratovi. Když říkáme, že Sókratés je člověk, termín „člověk“ označuje „toho, kdo má lidstvi““ a Sókratés je skutečně suppositum, které má lidství. Člověk jako takový je však neúplná entita, jakoby jsoucno v potenci, a proto člověk jako takový nesubsistuje, nýbrž subsistuje tento individuální člověk, jemuž náleží povaha (ratio) osoby. ${ }^{8}$

K povaze (ratio) osoby tedy náleží, že je to individuální (dokonale) subsistující od všech ostatních věcí odlišné rozumové suppositum, které zahrnuje všechna vymezení, která jsou v individuu realizována, včetně individuálních vymezení. Abstraktně uvažovaná přirozenost (lidství) naopak zahrnuje pouze esenciální vymezení věci a nezahrnuje tedy vymezení, která přirozenost individualizují. $\mathrm{V}$ jednoduchých separovaných entitách se přirozenost a osoba neliší, protože přirozenost není přijata v látce, která by ji individualizovala, nýbrž přirozenost takové entity subsistuje o sobě. Nakolik pak uvažujeme esenciální vymezení této jednoduché entity, chápeme ji jako přirozenost, když separovanou entitu uvažujeme jako subsistující, pojímáme ji jako osobu neboli suppositum. ${ }^{9}$

Potud Tomášův výklad. Z uvedeného textu je zřejmé, že přirozenost a osoba (a tedy i suppositum) se liší pouze v materiálních substancích,

nitas enim non est homo. Cujus ratio est, quia in significatione humanitatis, sive quidditatis, sive naturae, continentur tantum essentialia principia hominis, secundum quod homo est; non autem ea quae pertinent ad determinationem materiae, per quam natura individuatur, quae tantum continentur in significatione socratis, quia per ea socrates est hic, et divisus ab aliis: et ideo, quia humanitas non includit in sua significatione totum quod est in re subsistente in natura, cum sit quasi pars, non praedicatur: et quia non subsistit nisi quod est compositum, et pars habetur a suo toto, ideo anima non subsistit, sed socrates, et ipse est habens humanitatem.“

8 Tamtéž - „Homo autem significat utrumque, et essentialia, et individuantia, sed diversimode: quia significat essentialia determinate, individuantia vero indeterminate haec vel illa: et ideo homo, cum sit totum, potest praedicari de socrate, et dicitur habens humanitatem; sed quia esse indistinctum est incompletum, quasi ens in potentia, ideo homo non subsistit, sed hic homo, cui convenit ratio personae.“

9 Tamtéž - „Est ergo ratio personae quod sit subsistens distinctum et omnia comprehendens quae in re sunt; natura autem essentialia tantum comprehendit. In simplicibus autem non differt re natura et persona: quia natura non recipitur in aliqua materia per quam individuetur, sed est per se subsistens: tamen inquantum considerantur essentialia rei, sic dicimus ibi naturam; inquantum autem invenitur ibi aliquid subsistens, sic dicimus ibi personam.“ 
zatímco v jednoduchých separovaných entitách jsou přirozenost a osoba totožné. I když Tomáš výslovně nehovořil o stvořených jednoduchých entitách, přesto je z kontextu patrné, že se závěry netýkají pouze naprosto jednoduché entity Boží, ale také stvořených separovaných substancí.

Tomáš hájí tutéž tezi také na více místech svých pozdějších spisů a způsob jeho argumentace je značně podobný tomu, kterým jsme se právě zabývali. ${ }^{10}$ Druhý zmíněný přístup k řešení problematiky odlišnosti supposita a přirozenosti se nachází v Quodl. 2, 2, 2 (pochází z vánoční doby r. 1269), kde Tomáš odpovídá na otázku, zda se v andělu liší suppositum a přirozenost. $\mathrm{V}$ úvodu diskuse Tomáš nejprve vysvětluje, co se míní přirozeností a suppositem. „Přirozenost“ se vypovídá mnoha způsoby, jedním způsobem se však nazývá přirozeností samotná substance věci, nakolik „substance“ označuje esenci nebo kviditu věci. Tomáš v další diskusi rozumí přirozeností esenci nebo kviditu věci, kterou označuje definice. Suppositum je pak jednotlivá věc (singulare) v kategorii substance, které se nazývá hypostasis nebo také první substance. Protože jsou nám substance materiálních věcí, které jsou složené z látky a formy, více známé, uvažuje Tomáš nejdříve o vztahu přirozenosti a supposita v materiálních substancích. ${ }^{11}$

Tomáš nejprve hájí tezi, že esence nebo přirozenost materiální substance zahrnuje nejenom substanciální formu, ale také první látku. Tomášova argumentace ve prospěch tohoto názoru není z našeho hlediska důležitá, a proto ji ponecháme stranou. Dále Tomáš uvažuje o tom, zda je materiální suppositum totožné s esencí nebo přirozeností, a konstatuje, že tento problém řešil již Aristotelés v sedmé knize Metafyziky. ${ }^{12}$ Aristotelés

10 Srov. $O D P$ 9, 1; De spiritualibus creaturis 5 ad 9 um. Calcaterra, M. - Centi, T. (ed.). Quaestiones disputatae II. Turin, 1965 (dále jen QDSC); Sententia Libri De anima lect. 8, Opera Omnia XLV, 1 (ed. Leon.). Romae, 1984 (dále jen In III De anima); Summa theologiae I, 3, 3, Opera Omnia IV-XII (ed. Leon.). Romae, 1888-1906 (dále jen $S T h$.$) .$

11 Quodl. 2, 2, 2 - „... ad huius quaestionis intelligentiam oportet considerare quid sit suppositum et quid natura. Natura autem quamvis multipliciter dicatur, tamen uno modo dicitur natura ipsa substantia rei, ut dicitur in V metaph., secundum quod substantia significat essentiam vel quidditatem rei, vel quid est. Illud ergo significatur nomine naturae, prout hic loquimur de natura, quod significat definitio ... Suppositum autem est singulare in genere substantiae, quod dicitur hypostasis vel substantia prima: et quia substantiae sensibiles compositae ex materia et forma sunt magis nobis notae, ideo in eis primo videamus quomodo se habet essentia vel natura ad suppositum.“

12 Srov. ARISTOTELÉS. Metaphysica VII, 6, 1031a 15-1031b 28. Jaeger, W. (ed.). Oxford, 1957; viz též Tomášův komenář k těmto pasážím: Sententia super Metaphysicam lect. 5 (1362-1379), Cathala, M. R. -Spiazzi, R. M. (ed.). Turin, 1971 (dále jen In Metaph.). 
podle Tomáše ve svých úvahách stanovil, že v př́ípadě těch věcí, které se vypovídají o sobě (per se), je věc (res) a její kvidita (quod quid est) totožná, naopak v případě věcí, které se predikují akcidentálně (per accidens), tomu tak není. Např. člověk a kvidita člověka se neliší, protože termín „člověk“ označuje „živočicha dvounohého schopného chodit“. Naproti tomu bílá věc není zcela totožná s kviditou bílé (bělosti), protože „bílá“ označuje kvalitu, zatímco bílá věc je substance, která má kvalitu. ${ }^{13}$

Tomáš na tomto základě vymezuje následující princip: jestliže lze nějaké entitě přidat takovou dokonalost, která nenáleží k povaze (ratio) její přirozenosti, pak je $\mathrm{v}$ takové entitě suppositum odlišné od přirozenosti. Definice přirozenosti totiž zahrnuje pouze taková vymezení, která náleží k povaze druhu (quod est de ratione speciei), suppositum však zahrnuje nejenom druhová vymezení, ale také takové dokonalosti, které jsou přidány druhové přirozenosti. Proto suppositum označujeme na způsob celku, přirozenost však jako formální část. ${ }^{14}$

Protože je Boží bytí totožné s Boží esencí, není a nemůže být Boží esenci přidán žádný „přídavek“ (accidens), a proto je v Bohu suppositum totožné s přirozeností. $V$ andělu však suppositum a přirozenost nejsou zcela totožné, protože každý anděl má nějaké další dokonalosti, které nenáleží k povaze jeho druhu. Tak má každý anděl od své esence nebo přirozenosti reálně odlišný akt bytí a navíc jsou mu přidány některé (duchovní) akcidenty (těmito akcidenty Tomáš patrně míní rozumovou a volní mohutnost, jakož i jejich dílčí akty chápání a chtění, které náleží suppositu, ale nikoli přirozenosti anděla). ${ }^{15}$

13 Quodl. 2, 2, 2 - „Restat ergo considerandum, cum suppositum vel individuum naturale sit compositum ex materia et forma, utrum sit idem essentiae vel naturae. Et hanc quaestionem movet philosophus in libro VII metaph. Ubi inquirit, utrum sit idem unumquodque, et quod quid est eius: et determinat, quod in his quae dicuntur per se, idem est res et quod quid est rei; in his autem quae dicuntur per accidens, non est idem. Homo enim nihil est aliud quam quod quid est hominis: nihil enim aliud significat homo quam animal gressibile bipes; sed res alba non est idem omnino ei quod quid est album, quod scilicet significatur nomine albi: nam album nihil significat nisi qualitatem, ut dicitur in praedicamentis: res autem alba est substantia habens qualitatem."

14 Tamtéž - „Secundum hoc ergo, cuicumque potest aliquid accidere quod non sit de ratione suae naturae, in eo differt res et quod quid est, sive suppositum et natura. Nam in significatione naturae includitur solum id quod est de ratione speciei; suppositum autem non solum habet haec quae ad rationem speciei pertinent, sed etiam alia quae ei accidunt; et ideo suppositum signatur per totum, natura autem, sive quidditas, ut pars formalis.“

15 Tamtéž - „In solo autem deo non invenitur aliquod accidens praeter eius essentiam, quia suum esse est sua essentia, ut dictum est; et ideo in deo est omnino idem suppositum et natura. In Angelo autem non est omnino idem: quia aliquid accidit ei 
V odpovědi na druhou námitku téhož artikulu Tomáš potvrzuje v korpusu artikulu uvedené závěry a uvádí, že i když akt bytí není zahrnut v definici supposita, ani v definici přirozenosti, přece však bytí náleží suppositu. Protože akt bytí náleží suppositu a není zároveň zahrnut v definici přirozenosti, je zjevné, že suppositum a přirozenost nejsou totožné $\mathrm{v}$ žádné věci, jejíž esence a bytí se liší. ${ }^{16}$

Tolik Tomášův výklad. Jako klíčový se v Tomášově argumentaci jeví princip, že suppositum a přirozenost jsou odlišné v každé entitě, které lze přidat nějakou dokonalost, jež nenáleží k povaze její přirozenosti. Protože má podle Tomáše každá separovaná substance od své přirozenosti odlišný akt bytí, liší se v každé takové substanci také přirozenost a suppositum. Navíc jsou přirozenosti separovaných substancí přidány duchovní akcidenty rozumu a vůle, jakož i jejich dílčí akty chápání a chtění, a to jsou další od andělské přirozenosti odlišné dokonalosti, které svědčí ve prospěch odlišnosti přirozenosti a supposita v těchto nemateriálních entitách. Zde nás možná překvapuje, že Tomáš jako jeden z důvodů odlišnosti přirozenosti a supposita $\mathrm{v}$ separovaných substancích uvádí přítomnost duchovních akcidentů $\mathrm{v}$ těchto substancích. Tím Tomáš rozhodně netvrdí, že duchovní akcidenty a jejich dílčí akty ustavují suppositum, nebot' tyto akcidenty závisí na substanci jako na své př́ícině a předpokládají tak již zcela ustavenou substanci včetně jejího aktu bytí. ${ }^{17}$ Tomáš zmiňuje duchovní akcidenty a jejich dílčí akty v uvedené argumentaci patrně proto, že akcidenty (duchovní mohutnosti a jejich dílčí akty) nenáleží přirozenosti supposita jako takové, nýbrž suppositu, a tím se suppositum odlišuje od přirozenosti. Činnost totiž podle Tomáše nenáleží přirozenosti

praeter id quod est de ratione suae speciei: quia et ipsum esse Angeli est praeter eius essentiam seu naturam; et alia quaedam ei accidunt quae omnino pertinent ad suppositum, non autem ad naturam.“ Akt bytí, jak jsme již viděli, nechápe Tomáš samozřejmě jako kategoriální akcident, nýbrž v širším smyslu jako takovou dokonalost, která není součástí esence věci.

16 Quodl. 2, 2, 2 ad 2um - „Et ideo, licet ipsum esse non sit de ratione suppositi, quia tamen pertinet ad suppositum, et non est de ratione naturae, manifestum est quod suppositum et natura non sunt omnino idem in quibuscumque res non est suum esse." Na jiném místě (STh. III, 17, 2) v kontextu řešení otázky, zda je v Kristu jedno nebo dvojí bytí, Tomáš upřesňuje, jakým zposobem náleží bytí přirozenosti a suppositu. Akt bytí náleží suppositu i přirozenosti, ale nikoli tímtéž způsobem. Suppositu náleží akt bytí jako tomu, co má bytí; přirozenosti náleží bytí jako (formálnímu) principu, jímž (quo) má něco bytí. Srov. STh. III, 17, 2 ad 1 um - „... esse consequitur naturam, non sicut habentem esse, sed sicut qua aliquid est, personam autem, sive hypostasim, consequitur sicut habentem esse."

17 Srov. např. Summa contra Gentiles 4, 14, Opera Omnia XIII-XV (ed. Leon.). Romae, 1918-1930 (dále jen $S c G$ ) - „... omnia accidentia sunt formae quaedam substantiae superadditae, et a principiis substantiae causatae..." 
jako činiteli, nýbrž činnosti náleží suppositům. ${ }^{18} \mathrm{~V}$ tomto ohledu je patrná podobnost mezi vztahy konečného supposita $\mathrm{k}$ aktu bytí a $\mathrm{k}$ akcidentům: ani akt bytí, ani žádný z akcidentů není zahrnut v definici supposita, ale přesto obojí náleží suppositu. Patrně proto Tomáš obhajuje tezi o odlišnosti přirozenosti a supposita také s poukazem na př́tomnost akcidentů v suppositu. ${ }^{19}$

I když Tomáš v Quodlibet 2, 2, 2 nepoužil výše uvedený princip k to$\mathrm{mu}$, aby obhájil také odlišnost přirozenosti a supposita $\mathrm{v}$ materiálních substancích, je ve světle podaného výkladu tato odlišnost zcela zřejmá. V každém materiálním suppositu je přirozenost reálně odlišná od aktu bytí a navíc jsou přirozenosti materiálního supposita přidána individualizující vymezení, která působí numerickou multiplikaci více individuí téže přirozenosti, a proto se každé materiální suppositum reálně liší od své přirozenosti. $V$ materiálním suppositu jsou tedy k přirozenosti přidány individualizující principy, ${ }^{20}$ akt bytí a patrně i další akcidenty a jejich dílčí akty, jimiž je suppositum činné, a které tedy také náleží suppositu a nikoli přirozenosti.

V Quodlibet 2, 2, 2 tedy Tomáš v protikladu k jiným výše uvedeným textům hájí názor o reálné odlišnosti supposita a přirozenosti v každé ko-

18 STh. III, 20, 1 ad 2um - „Agere autem non attribuitur naturae sicut agenti, sed personae, actus enim suppositorum sunt et singularium..."

19 Tomášův výklad není podle našeho soudu v tomto ohledu zcela jasný. Není především jasné, co na ontologické rovině působí, že akcidenty a jejich dílčí akty (obecně činnosti) náleží suppositu a nikoli přirozenosti supposita. Jan od sv. Tomáše vykládá a rozvíjí Tomášovu myšlenku dále takto: vlastnost „být subjektem akcidentů“ náleží jako propriová vlastnost substanci a nikoli přirozenosti separované substance jako takové. Esenci separované substance je tedy přidána nějaká dokonalost, která je „mimo“ esenci této substance, díky níž je substance s to být základem akcidentů. Tato individuální přirozenosti substance přidaná dokonalost působí, že přirozenost a akcidenty se vzájemně sjednocují nesmíšeným způsobem (inconfuse et impermixte): je to pozitivní dokonalost, substanciální modus (subsistentia), který zakončuje (terminuje) individuální substanci, nikoli nakolik je existující, nýbrž nakolik je esence a přirozenost. Srov. IOANNES A SANCTO THOMA. Cursus theologicus, tomus II, disp. IV, art. 1, n. 9, Monachi solesmenses (ed.) [i. e. E. Boissard]. Paris, 1934, s. 434-435. V Janově argumentaci je cenný především postřeh, že k esenci substance je přidána nějaká dokonalost, která je mimo esenci substance, díky které je substance $s$ to být základem akcidentů. Tento postřeh je zcela $v$ souladu s naukou andělského doktora, Tomáš však tuto myšlenku, nakolik je nám známo, dále nerozvíjí. Janovy úvahy o formálním konstitutivním principu supposita přesahují podle našeho soudu rámec Tomášovy nauky, resp. Tomáš si vzhledem k problematice vztahu supposita a přirozenosti nepoložil tytéž otázky jako pozdější tradice, a proto na tyto otázky ani výslovně neodpovídá.

20 STh. I, 29, 2 ad 3 um - „... hypostasis et persona addunt supra rationem essentiae principia individualia..." 
nečné věci. Tomášovo pojetí supposita v Quodlibet je oproti jeho jiným úvahám více komplexní, nebot suppositum se liší od přirozenosti nejenom individualizujícími principy, což bylo Tomášovo hlavní kritérium pro rozlišení přirozenosti a supposita na jiných místech, ale také tím, že suppositu na rozdíl od přirozenosti náleží akt bytí a další akcidenty, jimiž je suppositum činné. Tento závěr je podnětem k otázce, zda Tomáš tímto tvrzením odmítl na jiných místech zastávaný názor o reálné totožnosti supposita a přirozenosti $\mathrm{v}$ separovaných substancích.

\section{Vnitřní jednota dvou uvedených řešení}

V odpovědi na výše uvedenou otázku se názory moderních badatelů liší. L. De Guzman Vicente se domnívá, že Tomáš vždy hájil tezi o reálném rozdílu přirozenosti a supposita v konečných substancích a zásadní význam připisuje Tomášovu výkladu z Quodlibet $2 .{ }^{21}$ Co se týče jiných textů, ve kterých Tomáš, jak se zdá, hájí reálnou totožnost přirozenosti a supposita v separovaných substancích, De Guzman Vicente se domnívá, že když Tomáš v těchto diskusích hovoří o jednoduchých entitách nebo substancích, pak tím ve skutečnosti míní pouze Boha, ve kterém je přirozenost a suppositum totožné. Slabinou jinak zajímavého De Guzmanova výkladu je především to, že Tomáš na více místech bud' výslovně tvrdí, že v separovaných substancích je suppositum a přirozenost reálně totožné nebo je tento závěr přinejmenším patrný z kontextu Tomášovy diskuse. ${ }^{22}$

O. Schweizer nabídl jiné vlivné řešení uvedené obtíže.$^{23}$ Podle Schweizera je třeba rozlišit dva zpo̊soby, jimiž Tomáš chápe suppositum: většinou suppositem míní o sobě úplnou a nesdělitelnou individuální substanci; na některých místech a obzvláště v Quodl. 2, 2, 2 rozumí Tomáš suppositem o sobě úplnou a nesdělitelnou individuální substanci spolu s jejím aktem bytí (a některými akcidenty, jak bych dodal). Když Tomáš chápe suppositum v prvním „užším“ smyslu, pak se přirozenost a sup-

21 Srov. DE GUZMAN VICENTE, L. De notione subsistentiae apud sanctum Thomam. Divus Thomas (Piac.) 1968, roč. 71, s. 397-422.

22 Srov. QDSC 5 ad 9 um, kde Tomáš hájí tezi, že v separovaných substancích individuum nepřidává žádnou reálnou dokonalost k přirozenosti druhu, protože esence a individuum jsou v těchto substancích totožné. Srov. též In III De anima, lect. 8, kde Tomáš hájí tutéž tezi. Na jiných výše uvedených místech je tento závěr podle našeho soudu dostatečně patrný z kontextu Tomášova výkladu - srov. výše pozn. 8 .

23 SCHWEIZER, O. Person und Hypostatische Union bei Thomas von Aquin. Freiburg, 1957, s. 85-89. 
positum separované substance neliší; jestliže však suppositum pojímá v druhém „širším“ smyslu, pak se přirozenost a suppositum liší v každé konečné substanci, protože žádná přirozenost konečné substance není totožná s aktem bytí (přirozenosti jako takové dále nenáleží akcidenty [činnosti], a tím se také liší od supposita). Tomáš podle Schweizera v Quodlibet 2 neodmítl svůj na jiných místech hájený názor na problém odlišnosti přirozenosti a supposita $\mathrm{v}$ separovaných substancích, nýbrž pouze rozšířil a pozměnil význam termínu „suppositum“. V Quodlibet 2 Tomáš na rozdíl od jiných výkladů jasně potvrdil, že akt bytí je součástí ontologické struktury supposita. Na tomto nic nemění ani fakt, že Tomáš v odpovědi na druhou námitku, jak jsme viděli výše, uvedl, že definice supposita nezahrnuje bytí. Definice supposita jako taková je omezena na jeho esenciální aspekt, ale v širším slova smyslu chápe Tomáš suppositum jako to, co má bytí. ${ }^{24}$ Schweizerova interpretace podle našeho

24 SCHWEIZER, O. Person und Hypostatische Union, s. 88-89. K podobným závěrům jako Schweizer dochází jiným způsobem H. Degl'Innocenti a J. Wippel. Podle Degl'Innocentiho lze chápat suppositum dvojím způsobem, jednak „materiálně“ (materialiter), a tehdy je synonymní s individuem, nebo „denominativně“ (denominative), přičemž takto je chápeme jako individuum spolu s aktem bytí. První i druhý způsob pojetí supposita odpovídá uvedenému rozlišení Schweizerovu. Srov. DEGL'INNOCENTI, U. H. De nova quadam ratione exponendi sententiam Capreoli de constitutione ontologica personae. Divus Thomas (Piac.) 1950, roč. 53, s. 321-338. Wippel ve svém výkladu nejprve připomíná, že Tomáš v diskusích o reálném rozdílu mezi esencí a aktem bytí v konečném jsoucnu velmi často užívá Boethiovu terminologii a tvrdí, že v konečném jsoucnu se liší „to, co je“ (quod est) a bytí (esse). V tomto kontextu klade Tomáš důraz na kviditativní aspekt konkrétní entity, a proto může říci, že konkrétní jsoucno (quod est) se liší od svého aktu bytí. Podobným způsobem podle Wippela uvažuje Tomáš o vztahu supposita a přirozenosti. Jako označuje termín „to, co je“ konkrétní existující subjekt, přičemž důraz je položen na kviditativní aspekt subjektu, tak lze chápat také termín „suppositum“ jako označující tentýž subjekt s tímtéž důrazem na kviditativní aspekt subjektu, přičemž suppositum navíc implikuje, že subjekt je ontologicky úplný a nesdělitelný. V tomto smyslu chápeme vztah individuální přirozenosti k suppositu jako vztah formální části ke konkrétnímu celku. Protože materiální substance jako konkrétní celky zahrnují vedle společné přirozenosti také s látkou spojená individualizující vymezení, hájil Tomáš vždy názor o odlišnosti supposita a přirozenosti v těchto entitách. Jelikož však separované substance nezahrnují taková s látkou spojená individualizující vymezení, může být $\mathrm{v}$ těchto substancích suppositum totožné s přirozeností - když totiž Tomáš klade důraz na kviditativní aspekt supposita. Na druhou stranu lze položit důraz na existenciální aspekt supposita a suppositum chápat jako individuální o sobě subsistující entitu, která vedle své přirozenosti zahrnuje také akt bytí. Takto pojaté suppositum se pak reálně odlišuje od přirozenosti, a to nejenom v materiálních substancích, ale také v separovaných substancích. Tímto způsobem chápe Tomáš suppositum v Quodlibetu 2, aniž by to však znamenalo nějakou zásadní změnu stanoviska vzhledem k jiným textům. Srov. WIPPEL, J. F. The Metaphysical Thought of Thomas Aquinas, s. 249-251. 
soudu dostatečně přesvědčivým způsobem ukazuje „vnitřní jednotu“ Tomášova pojetí vztahu supposita a přirozenosti a jeví se nám jako přijatelný výklad této interpretační obtíže. ${ }^{25}$

\section{Některá upřesnění dosavadního výkladu a shrnutí Tomášova řešení}

Některá upřesnění dosud podaného výkladu problematiky ontologické struktury supposita nacházíme především v Tomášových teologických pojednáních o problematice hypostatické unie. ${ }^{26} \mathrm{~V}$ rámci výkladu této christologické problematiky Tomáš upřesňuje některá výše uvedená tvrzení týkající se problematiky supposita, a proto se s některými úvahami krátce seznámíme.

Ve třetí části Theologické sumy $(2,2)$ odpovídá Tomáš na otázku, zda se božská a lidská přirozenost sjednotily v osobě. Ve třetí námitce Tomáš s odkazem na Boethia uvádí, že osoba je individuální substance rozumové přirozenosti. Protože druhá božská osoba přijala individuální lidskou přirozenost, zdá se, že přijatá lidská přirozenost je osobou. Sjednocení obou prrirozeností se tedy neuskutečnilo v osobě. ${ }^{27}$

$25 \mathrm{~V}$ pozdější (nejenom) tomistické tradici se diskuse o suppositu a jeho vztahu k přirozenosti primárně týká problému, co je formálním konstitutivním principem supposita, díky kterému je suppositum formálně subsistující a naprosto nesdělitelné. V bližším určení této formality se názory různých tomistů rozcházejí, ale v zásadě lze rozlišit dvě nejvýznamnější stanoviska. Podle prvního je touto formalitou individuální akt bytí substance nebo zaměření substance k aktu bytí (tuto tezi hájil např. Capreolus, De Aguirre nebo Billot), podle druhého stanoviska je touto formalitou zakončení (terminatio) individuální substanciální přirozenosti, které jí náleží, dříve než přijme akt bytí (tuto tezi hájil např. kardinál Kajetán nebo Jan od sv. Tomáše). S řešením této problematiky jsou spojeny nemalé obtíže, které svou povahou daleko přesahují rámec problému „suppositum a jeho vztah k přirozenosti“. V této souvislosti je třeba uvést, že Tomáš si otázku po formálním konstitutivním principu supposita ve svém díle nikde výslovně neklade, ani na ni explicitně neodpovídá. Tím samozřejmě netvrdíme, že tuto otázku nelze vzhledem k Tomášovu dílu smysluplně klást nebo se pokoušet na základě Tomášova ideového odkazu na tuto otázku odpovědět. K tomu srov. např. QUARELLO, E. Il problema scolastico della persona nel Gaetano e nel Capreolo. Divus Thomas (Piac.) 1952, roč. 55, s. 34-63; MULLANEY, T. U. Created Personality: The Unity of Thomistic Tradition. New Scholasticism 1955, roč. 29, s. 377-385.

26 K tomu srov. např. GORMAN, M. Metaphysische Themen in der Christologie. In SPEER, A. (ed.). Thomas von Aquin: Die Summa theologie. Werkinterpretationen. Berlin, 2005, s. 377-400; CROSS, R. The Metaphysics of the Incarnation: Thomas A. To Duns Scotus. Oxford : Oxford University Press, 2005 (především s. 51-71 \& s. 246257); STUMP, E. Aquinas. New York: Routledge, 2005 (především s. 407-426).

27 STh. III, 2, 2 obiec. 3 - „... sicut boetius dicit, in libro de duabus naturis, persona est rationalis naturae individua substantia. Sed verbum dei assumpsit naturam humanam individuam ... Ergo humana natura habet suam personalitatem. Non ergo videtur quod sit facta unio in persona." 
V odpovědi na námitku Tomáš popírá, že by každému individuu v kategorii substance, třebaže má rozumovou přirozenost, náležela povaha (ratio) osoby. Osobou je pouze takové rozumové individuum, které existuje o sobě. Osobou však není individuální věc, která existuje v nějaké dokonalejší věci. Proto Sókratova ruka, ačkoli je jednotlivou věcí, není osoba, nebot' neexistuje o sobě, nýbrž existuje pouze v rámci dokonalejšího celku. Osoba je individuální substance, ruka však není úplná substance, nýbrž je částí substance. I když je tedy lidská přirozenost jakési individuum v kategorii substance, jelikož neexistuje o sobě odděleně, nýbrž v dokonalejší osobě Božího slova, nemá vlastní „personalitu“. Sjednocení obou přirozeností se tedy uskutečnilo v osobě. ${ }^{28}$

Potud Tomášův výklad. Z uvedené diskuse je patrné, že individuální vymezení lidské přirozenosti jsou pouze nutnou, ale nikoli dostatečnou podmínkou toho, aby byla ustavena osoba, resp. suppositum. Jednotlivá substance jakožto přirozenost, jak je pro Tomáše zjevné na základě víry, není nutně suppositem, nýbrž suppositem je pouze taková jednotlivá substance, která existuje o sobě odděleně a je tak úplná substance (prout est in suo complemento). ${ }^{29}$ Úplnou substancí neboli suppositem je o sobě odděleně existující jednotlivá substance, která je zcela nesdělitelná: nesdílí bytí s žádnou jinou entitou ${ }^{30}$, ani není částí jiné substance, ani není přijata v jiné dokonalejší entitě.

28 STh. III, 2, 2 ad 3um - „... non quodlibet individuum in genere substantiae, etiam in rationali natura, habet rationem personae, sed solum illud quod per se existit, non autem illud quod existit in alio perfectiori. Unde manus socratis, quamvis sit quoddam individuum, non est tamen persona, quia non per se existit, sed in quodam perfectiori, scilicet in suo toto ... persona dicitur substantia individua, non enim manus est substantia completa, sed pars substantiae. Licet igitur humana natura sit individuum quoddam in genere substantiae, quia tamen non per se separatim existit, sed in quodam perfectiori, scilicet in persona dei verbi, consequens est quod non habeat personalitatem propriam. Et ideo facta est unio in persona.“ STh. III, 2, 3 ad 2 um - „... hypostasis significat substantiam particularem non quocumque modo, sed prout est in suo complemento. Secundum vero quod venit in unionem alicuius magis completi, non dicitur hypostasis, sicut manus aut pes. Et similiter humana natura in christo, quamvis sit substantia particularis, quia tamen venit in unionem cuiusdam completi, scilicet totius christi prout est deus et homo, non potest dici hypostasis vel suppositum, sed illud completum ad quod concurrit, dicitur esse hypostasis vel suppositum."

30 Od těla oddělená subsistující lidská duše není podle Tomáše z důvodu své „nedokonalé" subsistence osoba, protože je o sobě neustále zaměřena k tomu, aby sdílela své vlastní bytí s látkou. Srov. In III Sent., 5, 3, 2 - „... anima est pars humanae naturae, et non natura quaedam per se: et quia ratio partis contrariatur rationi personae, ut dictum est, ideo anima separata non potest dici persona: quia quamvis separata non sit pars actu, tamen habet naturam ut sit pars."; In III Sent., 5, 3, 2 ad 3um „... anima rationalis dicitur hoc aliquid per modum quo esse subsistens est hoc aliquid, etiam si habeat naturam partis; sed ad rationem personae exigitur ulterius quod sit totum et completum." Srov. též $Q D P 9,2$. 
Shrňme na závěr základní rysy Tomášovy koncepce ontologické struktury supposita v terminologii „celku a části“! Protože je Boží bytí naprosto jednoduché, je Boží přirozenost totožná se suppositem. Konečné suppositum lze pak podle Tomáše uvažovat dvěma způsoby: jednak jako o sobě ontologicky úplnou a nesdělitelnou individuální substanci; dále jako o sobě ontologicky úplnou a nesdělitelnou individuální substanci spolu s aktem bytí (a některými dalšími akcidenty, které však v dalším výkladu pomíjím). Rozlišme spolu s Tomášem dále materiální suppositum a nemateriální suppositum.

Když uvažujeme materiální suppositum prvním uvedeným způsobem, je to konkrétní celek, který se skládá ze společné přirozenosti a individualizujících vymezení (z individuální látky a látku vymezujících akcidentů), přičemž přirozenost není s individualizujícími vymezeními reálně totožná. Materiální suppositum má přirozenost jako svou formální část, (skrze) kterou je suppositum druhově vymezeno. Individualizující vymezení jsou sice nutnou, ale nikoli dostatečnou podmínkou k tomu, aby bylo ustaveno materiální suppositum; materiální suppositum je ustaveno pouze tehdy, když jednotlivá substanciální přirozenost existuje o sobě jako naprosto nesdělitelná, a je tak úplnou substancí.

Uvažme dále nemateriální suppositum prvním uvedeným způsobem. Přirozenost nemateriálního supposita je individuální sama sebou, nejsou jí přidána žádná individualizující vymezení. Tomáš ve svých úvahách neuvádí, že by k suppositu uvažovaném tímto způsobem náležely nějaké akcidenty, a proto lze uzavřít, že v tomto ohledu pojímá Tomáš nemateriální suppositum jako reálně nesložené a v tomto smyslu ontologicky nestrukturované.

Když uvážíme materiální suppositum druhým uvedeným způsobem, je jeho ontologická struktura více komplexní. Materiální suppositum je konkrétní celek, který se skládá z individuální substanciální přirozenosti a aktu bytí, přičemž individuální substanciální přirozenost je dále složená ze společné přirozenosti a individualizujících vymezení. Materiální suppositum jako konkrétní celek má (společnou) přirozenost jako formální část, díky které je suppositum druhově vymezené. Co se týče vztahu supposita a přirozenosti k aktu bytí, suppositum je podle Tomáše to, co má bytí, přirozenost se vztahuje k aktu bytí jako (formální) princip, jimzž má néco byti.j1 Materiální suppositum je tedy konkrétní celek, který se vztahuje k aktu bytí podobným zpo̊sobem, jako se vztahuje k bytí každé jsoucno, nebot jak suppositum tak i jsoucno lze charakterizovat jako to, co má bytí. Jako lze tedy

31 STh. III, 17, 2 ad 1um - „... esse consequitur naturam, non sicut habentem esse, sed sicut qua aliquid est, personam autem, sive hypostasim, consequitur sicut habentem esse.“ 
rozlišit $\mathrm{v}$ jsoucnu subjekt bytí a akt bytí, tak je také třeba v materiálním suppositu rozlišit subjekt bytí a akt bytí. Subjektem bytí v jsoucnu je esence neboli přirozenost, co se týče subjektu bytí v materiálním suppositu, je třeba vzhledem k Tomášovu rozlišení různých způsobů, jimiž se vztahuje přirozenost a suppositum k aktu bytí, rozlišovat dvojí subjekt: esence nebo přirozenost je subjektem, jímž (quo) má suppositum bytí, individuální substanciální přirozenost je subjektem, který (quod) má bytí. ${ }^{22}$

Uvažme dále nemateriální suppositum druhým uvedeným způsobem. Nemateriální suppositum je konkrétní celek, který se skládá ze substanciální přirozenosti, která je individuální sama sebou, a z aktu bytí. Proto lze říci, že nemateriální suppositum má přirozenost, jako má i akt bytí: přirozenost je takovou částí supposita, skrze kterou (quo) je suppositum druhově vymezené, akt bytí je částí supposita, jíž (quo) suppositum reálně existuje. V nemateriálním suppositu je však třeba přirozenost uvažovat dvěma odlišnými způsoby. Jednak je přirozenost formálním principem, jímž má suppositum bytí (subjekt quo), jednak je přirozenost samostatná o sobě existující a nesdělitelná věc (substance), která má bytí (subjekt quod). ${ }^{33}$

David Svoboda (1971), Katedra filosofie KTF UK

\section{ABSTRACT \\ DAVID SVOBODA \\ Ontological Structure of the "Supposit" in the Work of Thomas Aquinas}

The paper deals with Aquinas' concept of an ontological structure of the "supposit" [i.e. one being, complete as such, and therefore incommunicable] and is divided into three main parts. Firstly Aquinas' two different accounts of the problem are put forth. Secondly the author tries to show the "inner coherence" of these two apparently contradictory explanations. Finally on the basis of these considerations Aquinas' concept of an ontological structure of the "supposit" is presented in the "whole-part" terminology.

\section{Key words}

Thomas Aquinas, suppositum, nature, mereology

$32 \mathrm{~V}$ ontologické struktuře materiálního supposita je dále třeba rozlišit substanciální formu a první látku, ale této problematice nebudeme věnovat pozornost.

33 Srov. $S c G 2,54$. 